University of Nebraska - Lincoln

DigitalCommons@University of Nebraska - Lincoln

2013

\title{
Entrainment of Shovelnose Sturgeon by Towboat Navigation in the Upper Mississippi River
}

\author{
L. E. Miranda \\ U.S. Geological Survey \\ K. J. Killgore \\ U.S. Army Corps of Engineers
}

Follow this and additional works at: https://digitalcommons.unl.edu/usgsstaffpub

Miranda, L. E. and Killgore, K. J., "Entrainment of Shovelnose Sturgeon by Towboat Navigation in the Upper Mississippi River" (2013). USGS Staff -- Published Research. 737.

https://digitalcommons.unl.edu/usgsstaffpub/737

This Article is brought to you for free and open access by the US Geological Survey at DigitalCommons@University of Nebraska - Lincoln. It has been accepted for inclusion in USGS Staff -- Published Research by an authorized administrator of DigitalCommons@University of Nebraska - Lincoln. 


\title{
Entrainment of shovelnose sturgeon by towboat navigation in the Upper Mississippi River
}

\author{
By L. E. Miranda ${ }^{1}$ and K. J. Killgore ${ }^{2}$ \\ ${ }^{1}$ U.S. Geological Survey, Mississippi Cooperative Fish and Wildlife Research Unit, Mississippi State, MS, USA; ${ }^{2}$ U.S. Army \\ Corps of Engineers, Engineer Research and Development Center, Vicksburg, MS, USA
}

\begin{abstract}
Summary
Estimated number of shovelnose sturgeon Scaphirhynchus platorynchus impacted annually by towboat entrainment in navigation pools of the Upper Mississippi River were compared against estimates of fishery harvest and ambient population densities to evaluate the relevance of entrainment at the population level. Mean number of sturgeon entrained per kilometer of navigation was estimated at 0.02 , and mean number entrained annually considering towboat traffic was estimated at 0.38 sturgeon $/$ ha. Losses associated with entrainment were mostly lower than fishery harvest, although differences were not large. The two sources of mortality combined could potentially reduce the mature adult population to a level where it no longer has the reproductive capacity to replenish itself. Thus, through a combination of entrainment and fishing mortality shovelnose sturgeon may be looming near unsustainable population levels. These estimates are preliminary considering the many uncertainties associated with quantifying entrainment and its effects. Additional research is needed not only to derive better estimates, but also to develop options for managing entrainment.
\end{abstract}

\section{Introduction}

Wildlife-vehicle collisions have attracted public and research attention for decades (e.g. Stoner, 1925; Dickerson, 1939; Haugen, 1944; McClure, 1951; Way, 1970; Caletrio et al., 1996; Litvaitis and Tash, 2008). A parallel but nearly invisible phenomenon occurs in waterways. Boat propellers entrain fish (i.e. capture them into a turbulent flow) causing injury or mortality. However, because fish killed by entrainment are not as visible as road collisions, entrainment has received less attention, restricted to recent decades. Motorized vessels small and large (Silber et al., 2010; Work et al., 2010), but particularly large ones with single or multiple propellers more than two meters in diameter entrain large volumes of water, along with fish and aquatic fauna of all sizes (Odom et al., 1992; Gutreuter et al., 2003; Williams and O'Hara, 2010). Entrained fish are affected by propeller strikes or rapid changes in pressure, shear stress, and turbulence (Cada, 1990). Many survive entrainment (Killgore et al., 2001, 2011), but the likelihood of injury or mortality due to propeller strike increases with fish size (Killgore et al., 2011) and propeller diameter (Rommel et al., 2007).

The Upper Mississippi River supports one of the largest inland commercial towboat and barge traffic in the United States (NRCR, 2001). Towboats entrain large volumes of water often through twin propellers that generally exceed $2.4 \mathrm{~m}$ in diameter, and operate at a force of $13-54 \mathrm{~g}$. or more to push a raft of multiple barges. Moreover, towboat traffic can potentially generate continuous physical disturbances that affect the spatial distribution and abundance of some fish species in river channels (Gutreuter et al., 2006, 2010). It has been forecasted that towboat traffic may increase as navigation improvements are implemented and cost of fuel increases (NRCR, 2001). Also, the towboat industry is shifting from open-wheel propellers to Kort nozzle propellers, which produce a greater thrust and are potentially more damaging to fish (Maynord, 2000). Altogether, ongoing and impending changes in navigation are projected to increase fish entrainment.

The impacts of propeller-induced mortality on fish in rivers have received limited research attention. Fish injury and mortality associated with entrainment have been difficult to quantify because of the complexities posed by sampling behind towboats in navigation lanes (Odom et al., 1992; Gutreuter et al., 2003; Killgore et al., 2011). Gutreuter et al. (2003) were the first to empirically quantify towboat-associated entrainment mortality of fishes by trawling while following towboats to recover a fraction of the fish injured and killed. More recently, Killgore et al. (2011) developed a specialty net that attaches to the stern of a towboat to collect the fish entrained, including those injured or killed. These methodologies estimate rate of fish losses per towboat distance traveled. In general, these studies have shown that entrainment rates vary with fish species, size, and local habitat conditions, and that entrainment per kilometer of navigation is not high for most species. Nevertheless, entrainment rates have not been extrapolated according to total annual towboat travel distance to estimate total annual losses of key fish populations, such as the commercially important shovelnose sturgeon, Scaphirhynchus platorynchus, nor have they been used to assess the relevance of entrainment mortality on population well-being.

The shovelnose sturgeon is a species of concern as fishing and habitat modifications have threatened or reduced population densities throughout much of their range (Boreman, 1997; Morrow et al., 1998; Quist et al., 2002; Bajer and Wildhaber, 2007). This species occupies main-channel habitats during the entire year (Dettmers et al., 2001), feed on the bottom, and occasionally rise to the surface where they are exposed to navigation traffic. This species can also achieve large (approximately $1 \mathrm{~m}$ ) body lengths, and therefore has a higher probability of being struck by propellers (Killgore et al., 2011). Estimates of shovelnose sturgeon lost to towboat traffic are important to assess the effects of 
commercial navigation on sturgeon populations. Accordingly, an objective of this study was to estimate the number of shovelnose sturgeon lost annually to towboat entrainment. Although estimates of entrainment rates are important to gauge the effect of navigation on population density, more important questions are how much does entrainment losses impact the sustainability of shovelnose sturgeon populations, and if the loss severely impairs population size. Therefore, additional objectives were to provide context to entrainment losses by comparing the extent of shovelnose sturgeon entrainment-induced mortality against existing fishery harvest and population estimates, and to consider the relevance of entrainment losses on population sustainability.

\section{Methods}

\section{Losses to towboat entrainment}

Pool length, pool surface area, and towboat traffic were combined with estimates of shovelnose sturgeon injured or killed by towboat propellers to estimate total annual losses. Injury and mortality were identified forensically with a protocol similar to that established by Gutreuter et al. (2003) and described by Killgore et al. (2011). This protocol allowed separation of fish injured or killed by entrainment from fish with old wounds, already dead, or injured by the sampling protocol.

\section{Pool length and area}

The Upper Mississippi River includes a cascade of 26 pools, but our study was restricted to nine of the twelve lowermost pools (Fig. 1). Some of the study pools are largely riverine and narrow, whereas others have wide lacustrine basins, but all pools include side channels and backwaters (UMESC, 2010). Pools are typically wide and deep near the dam, and gradually become more riverine and shallow upstream. Pool length and surface area were obtained from Geographic Information Systems (GIS) data files available from UMESC, (2010).

\section{Towboat traffic}

Annual estimates of towboat traffic were the sum of complete upstream and downstream counts made at locks. Annual counts of towboats traversing each pool are made by lock operators and reported by USACE, (2010). Our analyses focused on counts made during the 5-year period between 2005 and 2009 to describe recent navigation levels. We assumed the best estimate of traffic through a pool was given by the mean of counts made at the upstream and downstream locks associated with each pool. Estimates were made as:

$t_{i}=\left[\frac{l_{i, u}+l_{i-1, u}}{2}\right]+\left[\frac{l_{i, d}+l_{i-1, d}}{2}\right]$

where,

$t_{i}=$ total annual traffic through pool $i ; l_{i, u}=$ annual count of towboats going upstream through lock $i$, and $l_{i, d}=$ annual count of towboats going downstream through lock $i$.

Navigation that occurs exclusively within a pool could not be estimated with available data, but this component is thought to be localized around harbors and other off-loading facilities using smaller vessels.

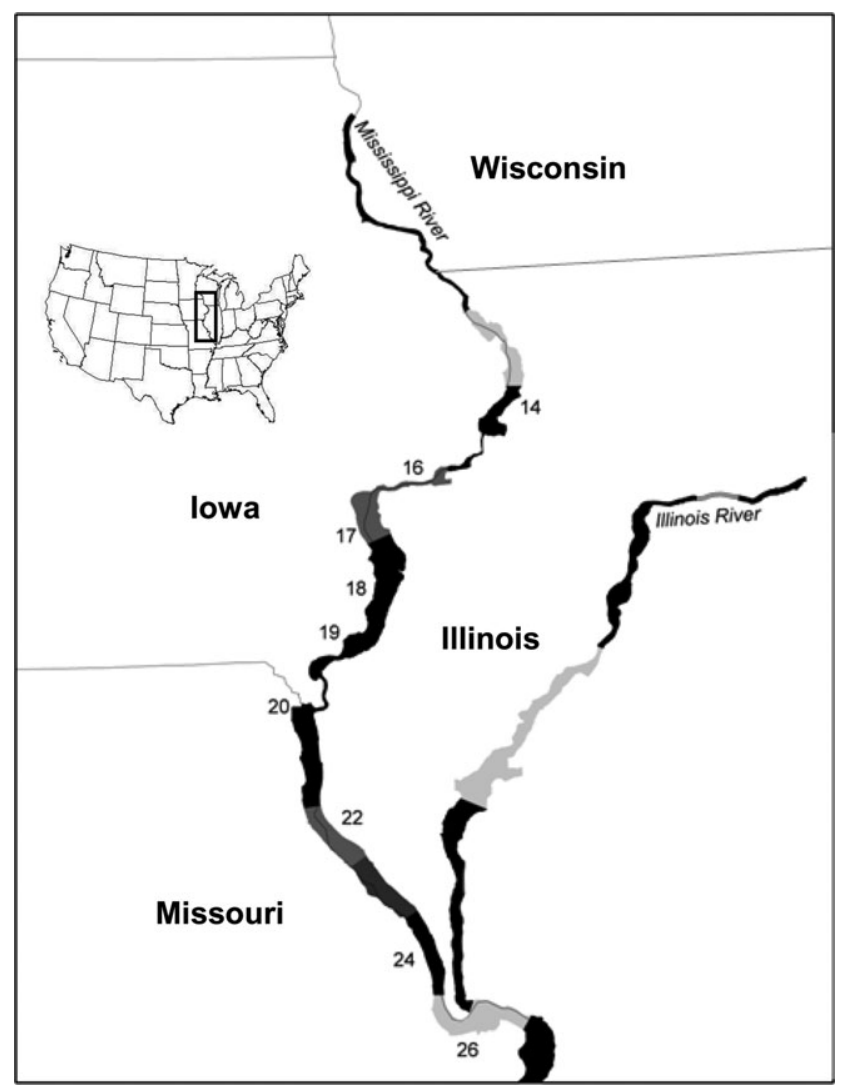

Fig. 1. Distribution of the study pools, Upper Mississippi River

\section{Fish losses}

Entrainment rates were estimated with a large net deployed behind a towboat of typical size (approximately 50-m long) operating in the Upper Mississippi River and pushing 15 loaded barges (Killgore et al., 2011). The net was $41.5 \mathrm{~m}$ long with an 11-m-long cod end, tapering in width and height from front to back. At the mouth, it was $9.1 \mathrm{~m}$ wide (the width of the towboat transom that encompassed the two propellers) and $4.0 \mathrm{~m}$ high (the distance from the deck to the bottom of the propeller). Mesh size was 3.8-cm stretch measure throughout. Sampling was limited to MayOctober because of the availability of the in-service towboat, as well as the navigational and sampling restrictions caused by seasonal icy waters. All samples were taken while the towboat was moving upstream, requiring greater power to maintain speed and position, so our loss estimates may represent a worst-case scenario. The towboat would continue traveling upstream during the night, and the following morning we would rejoin the vessel and resume sampling. This arrangement minimized impacts on the normal operations and progress of the towboat but precluded randomization of sampling sites. To maintain operational safety during net deployment and retrieval, all samples were taken during daylight hours. If shovelnose sturgeon move into shallow water during crepuscular periods (there are no data to suggest they do), then our estimates of fish losses are overestimates.

The total number of fish entrained was adjusted to estimate losses based on a logistic regression model (Killgore et al., 2011), which assigned a probability of a fish being injured or killed if entrained, and this probability increased with fish length (Fig. 2). Estimates were made as: 




Fig. 2. Relationship between fish length and probability of injury and mortality through a towboat propeller strike (logistic curves; Killgore et al., 2011) or to the fisheries

$\bar{e}_{r}=\frac{1}{n_{r}} \sum \frac{\sum\left(f_{r j l} \times P_{0.95, l}\right)}{d_{r j}}$

where,

$\bar{e}=$ total number of fish lost per kilometer; $n_{r}=$ total number of samples taken over all the pools sampled; $d_{j}=$ distance $(\mathrm{km})$ of the $j^{\text {th }}$ sample; $f_{j l}=$ a fish of $l$ length collected in the $j^{\text {th }}$ sample; and $P_{0.95, l}=$ the upper $95 \%$ confidence limit of the impact probability curve associated with a fish of $l$ length illustrated in Fig. 2.

Whereas samples were taken in multiple pools and seasons, $\bar{e}$ estimates were combined over all pools and seasons, to represent an average for the geographical range of the study pools. Consolidation of samples precluded accounting for any potential variability in the data associated with season, year, pool, or habitat type, but was necessary to (i) reduce the probability of estimates fluctuating widely due to high sample variability and small pool-specific sample sizes; (ii) produce more robust estimates of losses based on larger sample sizes; and (iii) develop generalized estimates suitable for decision making at broad spatial and temporal scales. Moreover, estimates of shovelnose sturgeon abundance against which entrainment estimates were compared (more below) were generally reported on a per year basis.

Mean impact per kilometer of navigation in each river was linked with towboat traffic, navigational distances, and pool surface areas to estimate total annual fish entrainment per hectare as:

$E=\frac{\bar{e} \cdot D \cdot T}{A}$

where,

$E=$ total annual number of fish impacted per hectare; $D=$ total navigational distance $(\mathrm{km}$; i.e., combined total length of study pools); $T=$ total traffic in the study pools estimated as $\sum t_{i}$ (equation 1); $A=$ total surface area for the study pools (ha) as defined by UMESC, (2010).

Estimates made with equation 3 were repeated with weights (estimated from recorded lengths as weight $=5.16$
$10^{-7}$ X FL $^{3.33}$; Quist et al., 1998) instead of numbers to compute biomass of fish injured/killed. The $95 \%$ confidence limits around $E$ were estimated by bootstrapping 1,000 times with equation 3 (Efron and Tibshirani, 1993) based on the observed distribution of $\bar{e}$, the observed distribution of $T$ in 2005-2009, and fixed values of $D$ and $A$. Estimates of $E$ are expressed relative to the total surface area of a pool, yet shovelnose sturgeon do not inhabit the entire pool and navigation is limited to defined lanes along a pool. Estimation relative to the entire pool was necessary to allow comparison with annual commercial harvest and population sizes that were reported on a per area basis, despite the fact that the fish might have been harvested in limited seasons and habitats within the pool.

\section{Entrainment relative to other enumerations}

Perhaps more important than how many fish are lost is how relevant are the losses to population sustainability. Assessing the effect on populations requires knowing population density, and such estimates are often not available, outdated, or have various limitations. Another approach to assessing losses is to compare estimates of injury and mortality against the harvest of commercial fisheries, although harvest estimates may also have various estimation limitations. Recognizing these limitations in data, we compiled and analyzed available estimates of fisheries harvest and population densities to contrast with $E$, and we offer these comparisons as exploratory evaluations suitable for making broad generalizations about the effect of towboat entrainment.

Shovelnose sturgeons are targeted by commercial fisheries. State natural resources agencies in the region have collected commercial harvest data according to pool from licensed commercial fishers since 1945, and these data are summarized and periodically updated by the Upper Mississippi River Conservation Committee (UMRCC). Commercial fishers are required to report their harvest, but reports are suspected to understate actual catch, although over time various regulations have been implemented to improve reporting (Rasmussen and Pitlo, 2004). Records included in our study were limited to the five most recent years of available data.

Various organizations have surveyed the fish communities of the Upper Mississippi River with methods that estimate catch rates (Rasmussen and Pitlo, 2004). Nevertheless, there are few estimates of shovelnose sturgeon population densities or total abundance. Exceptions include area-density estimates made by bottom trawl in Pool 26 (Dettmers et al., 2001), and a limited number of mark-recapture estimates (e.g., Helms, 1974; Garvey et al., 2009).

\section{Relevance of entrainment losses}

The significance of entrainment losses may be gauged by comparing losses against the level of mortality that would reduce a population to precarious levels. To assess overfishing, fishery scientists often compare the spawning potential (e.g., population fecundity) of exploited populations against that of unexploited populations (i.e., spawning potential ratio, $\mathrm{SPR}$ ). The SPR requires estimates of growth in length, age-related mortality, and age-related fecundity. SPR values higher than $0.2-0.3$ are considered sufficient to avoid overfishing for most species (Goodyear, 1993), but SPR as high as 0.4 have been suggested to protect long-lived species with lower reproductive capacity (Clark, 1991; Clark, 2002). The 
SPR model assumes additive mortalities when some compensatory mortality likely occurs. This compensation would ease the effects of fishing and entrainment; hence, model estimates are conservative in the sense that populations could sustain somewhat higher fishing and/or entrainment mortalities than predicted, but how much higher is unknown.

We estimated SPR for shovelnose sturgeon with growth, mortality, and fecundity values published for several pools of the Upper Mississippi River (Koch et al., 2009) and for the Middle Mississippi River (Tripp et al., 2009). The SPR was estimated as (Goodyear, 1993):

$S P R=\frac{P_{\text {impacted }}}{P_{\text {unimpacted }}}$

$$
P=\sum^{\mathrm{n}} E_{i} \sum \exp ^{-\left(M_{i j}+F_{i j}+T_{i j}\right)}
$$

where,

$\mathrm{n}=$ longevity in the population, fixed at 17 years; $E_{i}=$ mean fecundity of mature females of age $i$ in the absence of density-dependent inhibitions of growth estimated as $E_{i}=5^{*} 10^{-7}\left(\mathrm{FL}_{i}\right)^{3.821}$, with $\mathrm{FL}=$ fork length $(\mathrm{mm})$; $M_{i j}=$ natural mortality rate of fish age $i$ when they were age $j$, fixed at $0.11 ; F_{i j}=$ fishing mortality rate of fish age $i$ when they were age $j$ applied at several levels of $F$ and assuming a 61-cm minimum length limit (i.e., $F=0$ for fish $<61 \mathrm{~cm}$ ); $T_{i j}=$ entrainment mortality rate of fish age $i$ when they were age $j$ applied at several levels of $T$ and assuming the upper $95 \%$ confidence limit of the predicted relationship between fish length and the probability of injury by propeller strike for $30 \mathrm{~g}$ force (Killgore et al., 2011).

Longevity, $E_{i}, M_{i j}, F_{i j}$, and length limits were taken from Koch et al. (2009). The fishery $F_{i j}$ and towboats $T_{i j}$ impacted shovelnose sturgeons in different ways (Fig. 2). The fishery exerted mortality on fish equal to or larger than the minimum length limit, so that fish were either available to be harvested or not available. Entrainment exerted mortality across all fish lengths but the probability of mortality increased with length.

We conducted a sensitivity analyses to evaluate the response of SPR to deviations in the parameters n, $M, F$, and $T$. This analysis evaluated the elasticity of SPR to a $20 \%$ change in each parameter, individually. We chose $20 \%$ because it may not be unlikely that these parameters are measured with this much error. Elasticity reflects the proportional response of SPR to a proportional change in a parameter and is useful for estimating the relative influence of parameters on a model when the parameters are measured on different scales (Caswell, 2002). We calculated elasticity as the percentage change in SPR.

\section{Results}

\section{Fish injured by towboat entrainment}

Annual towboat traffic during 2005-2009 was relatively constant within pools. Among pools, traffic ranged from 1,890 towboats in Pool 14 to 2,209 in Pool 24, but was higher in Pool $26(3,967)$ as traffic bound for the Illinois River travels through the lower half of Pool 26. The Illinois River joins the Mississippi River approximately halfway through Pool 26. Thus, traffic in Pool 26 is high from the lock through the mouth of the Illinois River, but is reduced roughly in half upstream of this confluence. In terms of kilometers traveled (i.e., traffic $\mathrm{X}$ pool length), annual towboat traffic ranged from 68,000 km in Pool 17 to $364,000 \mathrm{~km}$ in Pool 26, and collectively during 2005-2009 averaged 1.1 million $\mathrm{km} /$ year in the nine study pools.

In all, 142 collections averaging 3.8- km long (range 0.99.1) were taken from May through October, 2006-2007. These collections totaled $570 \mathrm{~km}$ of passage and entrained 0.05 shovelnose sturgeons per kilometer (range 0-0.59). Fork length of the entrained shovelnose sturgeon averaged $47.5 \mathrm{~cm}$ (range 16.5 to $64.8 \mathrm{~cm}$ ). Shovelnose sturgeons were collected throughout all months sampled except in May. Shovelnose sturgeons were collected in all pools except pools 19,22 , and 26, but the species does occur in these pools. There was no apparent longitudinal entrainment gradient relative to pool position along the river.

Adjusting this total number of fish entrained to estimate loss (equation 2) resulted in an estimated 0.02 shovelnose sturgeons impacted per kilometer (range 0-0.18). Conversion of entrainment losses per kilometer to annual entrainment losses per hectare (equation 3) estimated shovelnose sturgeon losses averaged $0.38 \mathrm{fish} / \mathrm{ha}$ and $0.30 \mathrm{~kg} / \mathrm{ha}$ (Table 1).

\section{Entrainment relative to other shovelnose sturgeon enumerations}

Estimates of shovelnose sturgeon population densities suitable for evaluating entrainment losses were scarce (Table 1). Most estimates available in the literature reflect relative abundance (e.g. catch/day, catch/set) rather than absolute density. The estimated entrainment losses were generally lower than estimates of commercial harvest $(0.67 \mathrm{~kg} / \mathrm{ha})$, trawl catches (4.12 fish/ha, $2.02 \mathrm{~kg} / \mathrm{ha}$ ), and mark-recapture estimates (0.6-3.6 fish/ha). However, confidence limits of entrainment overlapped with some of the existing estimates (Table 1), suggesting that in some cases differences may not be large. We note that confidence limits combined various sources of variability (e.g., sample, pool, season, and year) and different estimates did not always reflect the same source of variability. These limitations make our comparisons only coarse approximations that need to be validated with further studies.

\section{Relevance of entrainment losses}

The SPR of shovelnose sturgeon dropped to 0.48 and 0.26 at 0.15 and 0.30 fishing mortality, respectively, if entrainment losses were zero (Fig. 3). If fishing mortality was zero, SPR dropped to 0.63 and 0.27 at 0.15 and 0.30 entrainment losses, respectively. If fishing mortality and entrainment losses were both 0.10 , modeled SPR was 0.36 . Recent estimates of total annual mortality of shovelnose sturgeon in pools of the Upper Mississippi River range between 0.20 and 0.35 (Koch et al., 2009; our rounding to the nearest 0.05), and possibly decrease over pools in an upstream direction (Koch et al., 2009). At the 0.20 level, total annual mortality may consist of about 0.10 natural mortality and 0.10 combined fishery exploitation and entrainment mortality. It is unknown how the latter 0.1 value is partitioned between fishery and entrainment; the upper dashed line in Fig. 3 (labeled $0.10)$ identifies all possible partition combinations that add up to 0.1 fishing plus entrainment mortality (i.e., 0.20 total mortality). Similarly, the 0.35 level of total mortality may consist of about 0.10 natural mortality and 0.25 combined fishing and entrainment mortality. It is also unknown how the 0.25 value is partitioned between the fishery and entrain- 
Table 1

Mean densities (number/ha) and biomass (kg/ha) of shovelnose sturgeon, Scaphirhynchus platorynchus, in pools of the Upper Mississippi River

\begin{tabular}{|c|c|c|c|}
\hline Estimate & Description & Number/ha & $\mathrm{Kg} / \mathrm{ha}$ \\
\hline Towboat entrainment & $\begin{array}{l}\text { Annual mean number and biomass injured or killed per hectare by } \\
\text { towboat propellers in } 9 \text { study pools estimated with equation } 3\end{array}$ & $0.38(0.22-0.55)$ & $0.30(0.16-0.45)$ \\
\hline Commercial fisheries & $\begin{array}{l}\text { Harvest in pools 14-26 of Upper Mississippi River in 2002-2006. } \\
\text { Data compiled by UMRCC (Upper Mississippi River } \\
\text { Conservation Committee) (2010). Confidence limits were } \\
\text { bootstrapped and reflect inter-annual and inter-pool variability }\end{array}$ & & $0.67(0.43-0.94)$ \\
\hline Bottom trawl & $\begin{array}{l}\text { Estimates made in Pool } 26 \text { of the Upper Mississippi River and the } \\
\text { connected Alton Pool of the Illinois River by Dettmers et al. (2001). } \\
\text { Confidence limits were estimated from standard errors and reflect } \\
\text { inter-sample variability }\end{array}$ & $4.12(2.58-5.66)$ & $2.02(1.32-2.72)$ \\
\hline Mark and recapture & $\begin{array}{l}\text { Helms (1974) estimated through mark and recapture the population } \\
\text { size of shovelnose sturgeon in Pool } 13 \text { in } 1971 \text { and } 1972 \text {. His } \\
1971 \text { estimate was about } 7,000 \text { fish }(5,000-11,00095 \% \text { CL) and his } \\
1972 \text { estimate was } 16,900 \text { fish }(11,900-29,000) \text {. Helms noted that the } \\
\text { higher estimates of } 1972 \text { were due to including a larger portion of the } \\
\text { pool in mark and recapture }\end{array}$ & $\begin{array}{l}0.62(0.44-0.97) \\
1.49(1.05-2.55)\end{array}$ & \\
\hline Mark and recapture & $\begin{array}{l}\text { Garvey et al. (2009) estimated through mark-recapture a population } \\
\text { size of } 136,000(95 \% \mathrm{CL}=116,000-160,000) \text { shovelnose } \\
\text { sturgeons }>\text { age } 6(55 \mathrm{~cm}), 322-\mathrm{km} \text { Middle Mississippi River, 2002-2005. } \\
\text { Values shown assume a bank-to-bank main channel area of } 15,400 \text { ha. }\end{array}$ & $3.56(0.06-7.06)$ & \\
\hline
\end{tabular}

Values in parentheses represent $95 \%$ confidence limits.

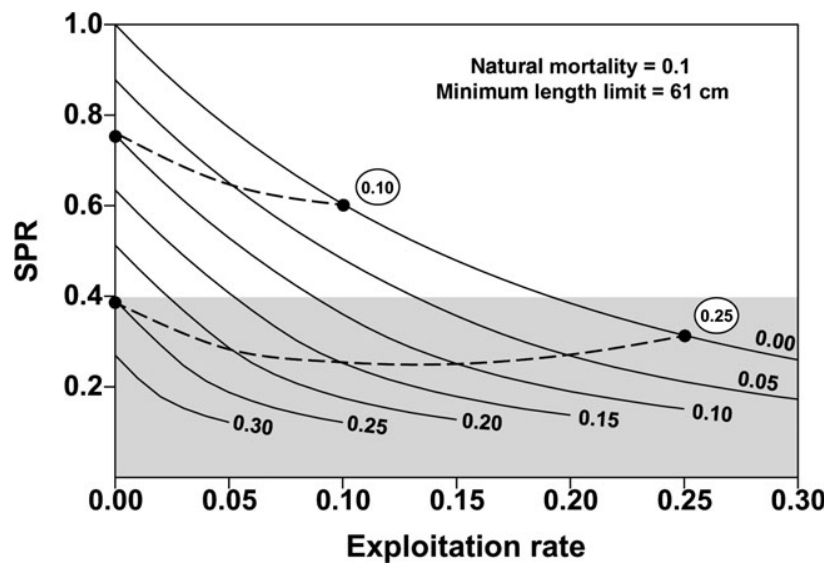

Fig. 3. Simulated relationships between exploitation rates (mortality due to the fishery) and spawning potential ratios (SPR) for shovelnose sturgeon, Scaphirhynchus platorynchus, at various entrainment loss rates (solid curves) and fixed natural mortalities. Dashed lines represent all possible combinations of exploitation and entrainment mortality that together with natural mortality add up to the value encircled next to the line

ment; the lower dashed line in Fig. 3 (labeled 0.25) identifies all possible partition combinations that add up to 0.25 fishing plus entrainment mortality (i.e., 0.35 total mortality). We suspect that the true split lies away from the extremes of each dashed line (i.e., away from the closed circles in Fig. 3). The region between the 0.10 and 0.25 dashed lines in Fig. 3 represents the range of possibilities for SPR. While we don't know precisely where SPR lies, and it most likely varies temporally and over pools, the region between dashed lines includes an area that dips below the 0.4 SPR considered a critical threshold for a long-lived species such as shovelnose sturgeon (Clark, 1991; 2002; Colombo et al., 2007).

Elasticity analysis showed how the SPR model responded to deviations in the parameters $\mathrm{n}, M, F$, and $T$ in equation 5. A $20 \%$ increase in $\mathrm{n}, M, F$, and $T$ produced a $16.1,4.5$, 16.4, and 14.1 percentage change in SPR, respectively. Thus, sensitivity of the SPR varied with parameter. Some of the deviations in percentage could be important particularly when SPR values are near their critical threshold.

\section{Discussion}

We estimated losses of shovelnose sturgeon due to entrainment by towboat navigation in pools of the Upper Mississippi River. Our estimations suggest that at current towboat navigation levels entrainment losses of shovelnose sturgeon may be approaching levels that rival fishery harvest. Comparison with densities estimated by trawling and mark-recapture also suggested entrainment generally was below ambient densities. The SPR analyses suggested that depending on current levels of fishing and entrainment mortality (both uncertain), the mature adult population may be dipping to levels where it no longer has the reproductive capacity to replenish itself, at least in some pools and some years.

Quantifying the impact of entrainment on fish populations is complex as there are many uncertainties involved. These uncertainties are associated with quantifying the level of entrainment, quantifying the fraction of entrained fish actually harmed, quantifying ambient fish densities to gauge the relevance of entrainment, and pinpointing the threshold level of entrainment mortality that would actually threaten a population. Aside from estimation difficulties, population densities can vary greatly among years depending on environmental fluctuations that affect the abundance and distribution of fishes and sampling efficiency. These fluctuations are reflected mainly in numerical densities of juveniles but are often transmitted into older age groups. Accordingly, more precise and representative collection methods may not substantially reduce uncertainties. Considering these limitations, the estimates we derived are exploratory, but are the best available for this system.

Questions about the reliability of data can often delay management action while decision-makers debate whether to take a precautionary stance and initiate conservation activities, or wait until stronger data are available. Uncertainty often results in calls for further studies, which could improve 
or validate our estimates. Nevertheless, whether our estimates overestimate or underestimate entrainment mortality, or whether additional estimates are sought, it is clear that entrainment has the potential to impact shovelnose sturgeons. Thus, along with additional estimates, future research may also need to consider development of options for managing entrainment.

Our analysis suggests that for large-bodied, channel-dwelling species such as the shovelnose sturgeon, entrainment can be an important source of mortality rivaling that of fishing mortality. The link between vulnerability and large-body size is related to the higher probability of propeller impact on large fish as well as life-history characteristics of large-bodied, slow-recovering species that typically include long lifespan, maturation late in life, and iteroparous reproductive strategy. Nevertheless, entrainment is only one of several human-mediated disturbances that may threaten fish populations in river systems. Lack of adequate fish passage, introduced species, habitat degradation in side channels and backwaters, and other disturbances are also likely to negatively impact populations, and exacerbate the effects of entrainment.

\section{Acknowledgements}

This study was funded by the U.S. Army Corps of Engineers, Rock Island District, and conducted by the Environmental Laboratory, Engineer Research and Development Center. Technical support was provided by Mark Cornish and Thomas Keevin, U.S. Army Corps of Engineers. Q. Phelps, S. Riffel, H. Schramm, and I. Vining provided helpful reviews. Any use of trade, product, or firm names is for descriptive purposes only and does not imply endorsement by the U.S. Government. Permission to publish this document was given by the Chief of Engineers, U.S. Army Corps of Engineers.

\section{References}

Bajer, P. G.; Wildhaber, M. L., 2007: Population viability analysis of Lower Missouri River shovelnose sturgeon with initial application to the pallid sturgeon. J. Appl. Ichthyol. 23, 457-464.

Boreman, J., 1997: Sensitivity of North American sturgeons and paddlefish to fishing mortality. Environ. Biol. Fishes 48, 399405.

Cada, G. F., 1990: A review of studies relating to the effects of propeller-type turbine passage on fish early life stages. N. Am. J. Fish. Manag. 10, 418-426.

Caletrio, J.; Fernandez, J. M.; Lopez, J.; Roviralta, F., 1996: Spanish national inventory on road mortality of vertebrates. Global Biodiversity $\mathbf{5}, 15-18$.

Caswell, H., 2002: Matrix population models: construction, analysis and interpretation, Sinauer Associates, Sunderland, Massachusetts.

Clark, W. G., 1991: Groundfish exploitation rates based on life history parameters. Can. J. Fish. Aquat. Sci. 48, 734-750.

Clark, W. G., 2002: F35\% revisited ten years later. N. Am. J. Fish. Manag. 22, 251-257.

Colombo, R. E.; Garvey, J. E.; Jackson, N. D.; Brooks, R.; Herzog, D. P.; Hrabik, R. A.; Spier, T. W., 2007: Harvest of Mississippi River sturgeon drives abundance and reproductive success: a harbinger of collapse? J. Appl. Ichthyol. 23, 444-451.

Dettmers, J. M.; Gutreuter, S.; Wahl, D. H.; Soluk, D. A., 2001: Patterns in abundance of fishes in main channels of the Upper Mississippi River System. Can. J. Fish. Aquat. Sci. 58, 933-942.

Dickerson, L. M., 1939: The problem of wildlife destruction by automobile traffic. J. Wildl. Manag. 3, 104-116.

Efron, B.; Tibshirani, R. J., 1993: An introduction to the bootstrap. Chapman \& Hall, New York.
Garvey, J. E.; Heist, E. J.; Brooks, R. C.; Herzog, D. P.; Hrabik, R. A.; Killgore, K. J.; Hoover, J.; Murphy, C., 2009: Current status of the pallid sturgeon (Scaphirhynchus albus) in the Middle Mississippi River: habitat, movement, and demographics. Engineer Research and Development Center, U.S, Army Corps of Engineers, Vicksburg, Mississippi.

Goodyear, C. P., 1993: Spawning stock biomass per recruit in fisheries management: foundation and current use. Can. Spec. Publ. Fish. Aquat. Sci. 120, 67-81.

Gutreuter, S.; Dettmers, J. M.; Wahl, D. H., 2003: Estimating mortality rates of adult fish from entrainment through the propellers of river towboats. Trans. Am. Fish. Soc. 132, 646661.

Gutreuter, S.; Vallazza, J. M.; Knights, B. C., 2006: Persistent disturbance by commercial navigation alters the relative abundance of channel-dwelling fishes in a large river. Can. J. Fish. Aquat. Sci. 63, 2418-2433.

Gutreuter, S.; Vallazza, J. M.; Knights, B. C., 2010: Lateral distribution of fishes in the main-channel trough of a large floodplain river: implications for restoration. River Res. Appl. 26, 619-635.

Haugen, A. O., 1944: Highway mortality in southern Michigan. J. Mammal. 25, 177-184.

Helms, D., 1974: Shovelnose sturgeon in the Mississippi River, Iowa. Iowa Conservation Commission, Iowa Fisheries Research Technical Series 74-3, Des Moines.

Killgore, K. J.; Maynord, S. T.; Chan, M. D.; Morgan, R. P., II, 2001: Evaluation of propeller-induced mortality on early life stages of selected fish species. N. Am. J. Fish. Manag. 21, 947-955.

Killgore, K. J.; Miranda, L. E.; Murphy, C. E.; Hoover, J.J. Wolff, D.; Maynord, S. T.; Keevin, T.; Cornish, M., 2011: Fish entrainment rates through towboat propellers in the Upper Mississippi and Illinois rivers. Trans. Am. Fish. Soc. 140, 570581.

Koch, J. D.; Quist, M. C.; Pierce, C. L.; Hansen, K. A.; Steuck, M. J., 2009: Effects of commercial harvest on shovelnose sturgeon populations in the upper Mississippi River. N. Am. J. Fish. Manag. 29, 84-100.

Litvaitis, J. A.; Tash, J. P., 2008: An approach toward understanding wildlife-vehicle collisions. Environ. Manag. 126, 103-106.

Maynord, S. T., 2000: Power versus speed for shallow draft navigation. J. Waterw. Port Coast. Ocean Eng. 126, 103-106.

McClure, H. E., 1951: An analysis of animal victims on Nebraska's highways. J. Wildl. Manag. 15, 410-420.

Morrow, J. V., Jr; Kirk, J. P.; Killgore, K. J.; George, S. G., 1998: Age, growth, and mortality of shovelnose sturgeon in the lower Mississippi River. N. Am. J. Fish. Manag. 18, 725-730.

NRCR (National Research Council, 2001: Inland navigation system planning: the Upper Mississippi River-Illinois Waterway, National Academy Press, Washington, D.C.

Odom, M. C.; Orth, D. J.; Nielsen, L. A., 1992: Investigation of barge-associated mortality of larval fishes in the Kanawha River. Va. J. Sci. 43, 41-45.

Quist, M. C.; Guy, C. S.; Braaten, P. J., 1998: Standard weight (Ws) equation and length categories for shovelnose sturgeon. N. Am. J. Fish. Manag. 18, 992-997.

Quist, M. C.; Guy, C. S.; Pegg, M. A.; Braaten, P. J.; Pierce, C. L.; Travnichek, V. H., 2002: Potential influence of harvest of shovelnose sturgeon populations in the Missouri River system. N. Am. J. Fish. Manag. 22, 537-549.

Rasmussen, J. L.; Pitlo, J. M., 2004: UMRCC fisheries compendium. 3rd edition Upper Mississippi River Conservation Committee, Fish Technical Committee, Rock Island, Illinois.

Rommel, S. A.; Costidis, A. M.; Pitchford, T. D.; Lightsey, J. D.; Snyder, R. H.; Haubold, E. M., 2007: Forensic methods for characterizing watercraft from watercraft-induced wounds on the Florida manatee (Trichechus manatus latirostris). Mar. Mamm. Sci. 23, 110-132.

Silber, G.; Slutsky, J.; Bettridge, S., 2010: Hydrodynamics of a ship/ whale collision. J. Exp. Mar. Biol. Ecol. 391, 10-19.

Stoner, D., 1925: The toll of the automobile. Science 61, 56-58.

Tripp, S. J.; Phelps, Q. H.; Colombo, R. E.; Garvey, J. E.; Burr, B. M.; Herzog, D. P.; Hrabik, R. A., 2009: Maturation and reproduction of shovelnose sturgeon in the Middle Mississippi River. N. Am. J. Fish. Manag. 29, 730-738.

UMESC (Upper Mississippi River Environmental Sciences Center, 2010: Data visualization tools. http://www.umesc.usgs.gov/ data_library/tools/data_visualization_tools.html(accessed on 3 December 2009). 
UMRCC (Upper Mississippi River Conservation Committee, 2010 State commercial fishing regulations by species. http://www.umrcc.org/CommFishSpecies.html.(accessed on 12 December 2010).

USACE (U.S. Army Corps of Engineers, 2010: U.S. Army Corps of Engineers, Upper Mississippi River System, Omni reports. http://www2.mvr.usace.army.mil/NIC2/default.cfm(accessed on 3 December 2009)

Way, J. M., 1970: Wildlife on the motorway. New Sci. 47, 536-537.

Williams, R.; O’Hara, P., 2010: Modelling ship strike risk to fin, humpback and killer whales in British Columbia, Canada. J. Cetacean Res. Manag. 11, 1-8.
Work, P. A.; Sapp, A. L.; Scott, D. W.; Dodd, M. G., 2010: Influence of small vessel operation and propulsion system on loggerhead sea turtle injuries. J. Exp. Mar. Biol. Ecol. 393, 168-175.

Author's address: L. E. Miranda, U.S. Geological Survey, Mississippi Cooperative Fish and Wildlife Research Unit, P.O. Box 9691, Mississippi State, MS 39762, USA.

E-mail: smiranda@usgs.gov 